\title{
SCylax of Caryanda, Pseudo-Scylax, ANd THe PARIS PERIPLUS: RECONSIDERING THE ANCIENT TRADITION OF A GEOGRAPHICAL TEXT
}

Ivan Matijašićc

ABSTRACT: The Periplus preserved in the manuscript Parisinus suppl. gr. 443, and erroneously ascribed to Scylax of Caryanda (sixth century BC), is the oldest extant specimen of ancient Greek periplography: it belongs to the second half of the fourth century. In the present article, all the testimonies on the ancient tradition of both Scylax and the Paris Periplus are carefully evaluated. The aim is to determine when and why the Paris Periplus was mistakenly ascribed to Scylax and to clear any doubts on the alleged authorship of this ancient geographic work. The confusion, or the wilful falsification, is evident in Strabo: he knew of Scylax's voyage in the East and at the same time was acquainted with the text of the Paris Periplus, which he ascribed to this famous ancient seafarer. Greek and Latin authors of the Roman Imperial age knew the Paris Periplus, but many followed slavishly the erroneous ascription to Scylax of Caryanda. When Marcianus of Heraclea in the early Byzantine age collected his corpus of ancient Greek geographers he also ascribed the Paris Periplus to Scylax, thus handing down the error to the copyist of the Paris. suppl. gr. 443.

KEYWORDS: Ancient Greek geography; periplography; Scylax of Caryanda; Marcianus of Heraclea; Paris. suppl. gr. 443.

\section{Introduction}

The Periplus of the so-called Pseudo-Scylax is an ancient clockwise description of the coast of the Mediterranean and of the Pontus Euxinus, beginning with the Pillars of Heracles (Strait of Gibraltar) and ending with an account of the Atlantic coast south of the Pillars. The text of the Periplus is preserved in a thirteenth century manuscript in the Bibliothèque Nationale de France in Paris, Paris. suppl. gr. 443 (D). ${ }^{2}$ The few other manuscripts which transmit the text are actually apographs of the Parisinus. Richard Bentley, the

\footnotetext{
1 Westfälische Wilhelms-Universität Münster, Seminar für Alte Geschichte/Institut für Epigraphik. Email: imatijasic@gmail.com. This article is a revised version of a paper delivered at the International Conference Antiquitates Sollemnia Antidoron Mate Suić, Zagreb and Zadar, $3^{\text {rd }} 7^{\text {th }}$ November 2015. I am very grateful to the organizer, Prof. Bruna Kuntic Makvić, for the opportunity to speak at the conference. Moreover, I wish to express my gratitude to Sergio Brillante, Aude Cohen-Skalli, and Enrico Emanuele Prodi for their invaluable suggestions on the first draft of this article. Unless otherwise noted, all translations of Greek and Latin texts are my own.

2 For the description of the ms. and its history, see Diller 1952:19-22 and Marcotte 2000:LXXVII-LXXXIV.
} 
greatest British classical scholar of his time, called the transmitted text of the Pseudo-Scylax "one of the most corrupted books in the world". 3 He was definitely being realistic.

Many have struggled with the text of the Pseudo-Scylax. The first (inaccurate) edition was published in 1600 by the Jesuit scholar David Höschel. A very young Isaac Vossius produced a valuable edition with commentary in 1639, and many scholars have since dealt with this arduous text.4 Müller's 1855 edition in the Geographi Graeci Minores (vol.1) has been the standard one for more than a century and a half (even if B. Fabricius', alias Heinrich Theodor Dittrich, 1878 edition is considered more accurate), until Graham Shipley in 2011 provided a new text with introduction and English translation. 5

Previous scholarship on Pseudo-Scylax's Periplus has concentrated on the question of authorship. The debate probably did not enjoy as wide a readership as the recent uncovering of Elena Ferrante's identity, but it spanned over four centuries. A review of all the different opinions has been synthetically provided in Diller's fundamental book on the tradition of the minor Greek geographers. ${ }^{6}$ The common reference to Pseudo-Scylax rests upon the opening pages in $\mathrm{D}$ where the first line gives the alleged name of the author and the title

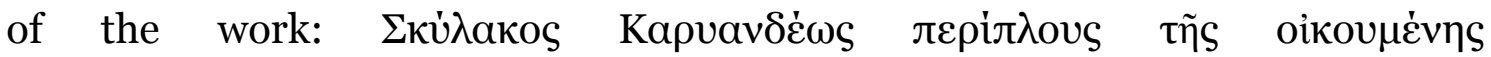
("Circumnavigation of the known world of Scylax of Caryanda").7 Scylax of Caryanda is mentioned in Herodotus' Histories (4.44) as the leader of an expedition to the river Indus in the last decades of the sixth century BC. However, the identification is mistaken and the work belongs to the fourth century BC: this conclusion has been recently expanded by Didier Marcotte, claiming that the author was an Athenian who wrote around 338-335 BC, and

\footnotetext{
3 Bentley 1699:327.

4 See Diller's chronologically organised bibliography (1952:50-99).

5 Sergio Brillante is currently working on a new edition for the CUF Série (Les Belles Lettres).

6 Diller 1952:48-99 (bibliography); the index of geographers (188-189) helps to identify specific items within the bibliography. Fabricius 1841,1844 also provided a comprehensive and useful review of earlier bibliography with his own annotations.

${ }_{7}$ See Paris. Suppl. gr. 443, f.62. Cf. Shipley 2011:1-2. See below pp.12-13 for further discussion.
} 
accepted in Shipley's edition. ${ }^{8}$ In the following pages we should refer to the work preserved in D with "Paris Periplus" (instead of Pseudo-Scylax). 9

A divergent opinion has been suggested by Gerard Joannes Vossius (1577-1659) in the second edition of his De historicis Graecis: he considered the work of the Paris Periplus to be an epitome of an original periplus by the Scylax mentioned in Hdt. 4.44, compiled not before Polybius and belonging perhaps to the age of Constantine Porphyrogenitus (tenth century AD). ${ }^{10}$ More recent works on the Paris Periplus have modified and expanded Vossius' hypothesis. In

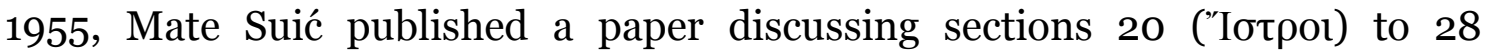
(Xáoves) of the Paris Periplus, i.e., the Adriatic coast from the Istrian peninsula to Epirus. ${ }^{11}$ He was confident of the fact that the Periplus, originally the work of the sixth-century-BC Scylax of Caryanda, is full of interpolations, and tried to restore the core text. ${ }^{12}$ The same opinion was independently developed and examined in depth by Aurelio Peretti in many published articles and one important and thorough book. ${ }^{13}$ However, the opinion that considers the Paris Periplus originally written by the sixth-century-BC Scylax of Caryanda is supported by scanty textual evidence. We shall review it, together with the remaining ancient tradition on this Carian explorer and seafarer.

\section{Herodotus and Aristotle on Scylax of Caryanda}

Ancient tradition on the figure of Scylax begins with Herodotus' account of his explorations to the river Indus (4.44 [T3a Kaplan]):

\footnotetext{
8 Marcotte 1986, 2016; Counillon 2004:24-26; cf. Shipley 2011:6-7. See also the classical overview in Müller 1855:XXXIX-L.

9 Following partially Marcotte 2016. The abbreviated reference to individual passages of this text will be, however, given in the generally accepted abbreviation, i.e., Ps.-Scyl.

10 Vossius 1651:124-126 (ed. Westermann, 1838:166-167). In his previous edition of the De historicis Graecis (1624), Vossius dated both Scylax and Pseudo-Scylax in the time of Alexander, following Scaliger (cf. Diller 1952:49, 58). Both scholars were relying heavily on Marcianus of Heraclea (see below).

${ }^{11}$ Suić 1955. His conclusions on the Adriatic coast were recently discussed by Counillon 2007 and Vitelli Casella 2011.

${ }^{12}$ Suić was influenced by an important article on the Adriatic coast where the author improperly stated: "Scylax of Caryanda was able to write up the human and perhaps the physical geography of the Illyrian coast. He may well have been standing on the shoulders of Phocaean pioneers" (Beaumont 1936:172).

13 Peretti 1979.
} 


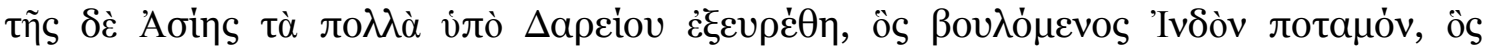

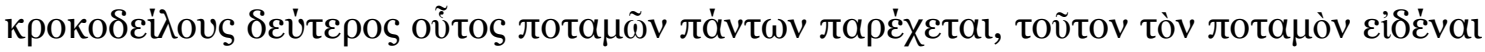

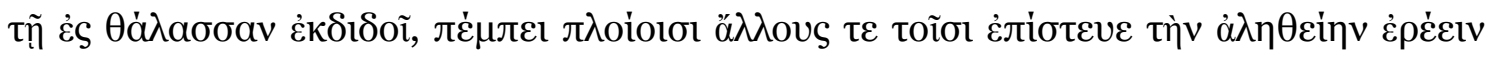

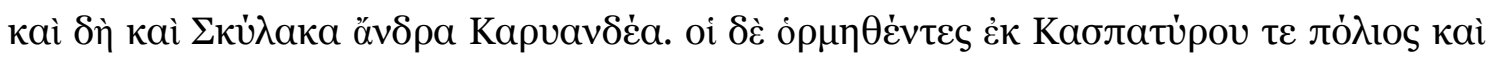

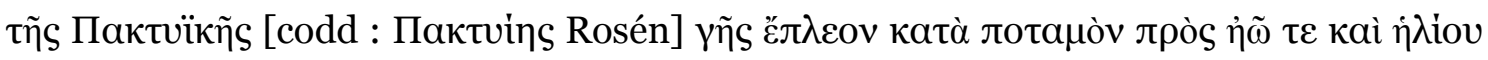

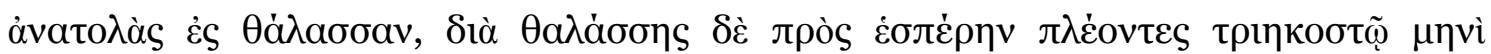

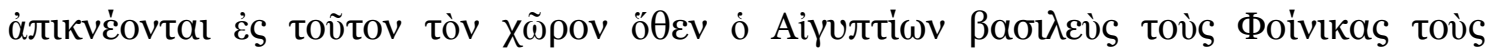

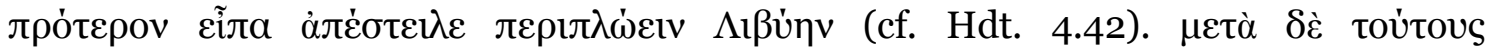

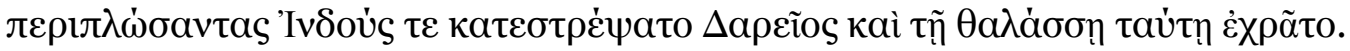

Most of Asia was discovered by Darius: since he wanted to know where the river Indus, which of all rivers is the second to have crocodiles, flows into the sea, he sent ships with men whose word he trusted, and among them Scylax, a man of Caryanda; they set out from the city of Caspatyros and the Pactyic region, and sailed down the river towards the east and the sunrise till they came to a sea; and voyaging over the sea westwards, they came in the thirtieth month to that place whence the Egyptian king sent the aforementioned Phoenicians to sail round Libya. After this circumnavigation, Darius subdued the Indians and made use of this sea.

Herodotus' account is geographically inaccurate, since he did not have direct knowledge of the Indus - which does not mean he was lying on purpose. Starting from the city of Caspatyros, or more correctly Caspapyros, ${ }^{14}$ which coincides probably with Kabul or Peshawar in the Gandhara region, Herodotus makes Scylax and his companions sail the river Indus eastward, even if the course of the river is actually Southwest. ${ }^{15}$ Nonetheless, the journey proceeds westwards over the sea, which means probably the present-day Arabian sea, and ends where the journey of the Phoenicians described in Hdt. 4.42 had begun, somewhere in the Gulf of Suez. Even if Herodotus' text contains some inaccuracies, it is evident that the geographical area covered by Scylax's journey has nothing to do with the Paris Periplus preserved in D.

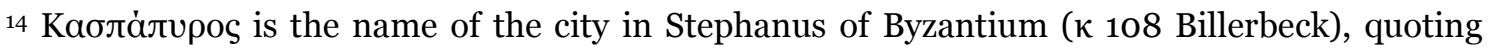
Hecataeus of Miletus (FGrHist 1 F295). It is also the reading of some Herodotean manuscripts (see the apparatus criticus in Rosén's edition, 1987).

15 See Macan 1895:30-31; Aldo Corcella's commentary in Corcella, Medaglia, Fraschetti 1999:268; Kaplan 2009.
} 
Herodotus in 4.44 does not speak of any written account (he actually uses the verb عip $\rho$ "speak, tell”), but some kind of official report on the journey was probably expected from Scylax, as was the case in Democedes of Croton's explorations in South Italy: see Hdt. 3.134-137, where the report (or inventory)

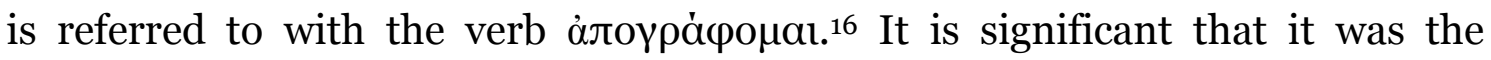
Persian king Darius I who entrusted both Scylax and Democedes with the respective expeditions.

Direct evidence of a written account of Scylax's explorations comes from Aristotle. In the Politics, the philosopher quotes Scylax as the source of the statement that in India "the kings are physically very different from their subjects, etc." 17 The observation seems to represent the earliest hint to the Indian caste system and at the same time shows that Scylax's account included political and ethnographic remarks in his work. It also clarifies the character and purposes of the earliest peripli such as those of Scylax and Democedes: commissioned by a sovereign, the reports were supposed to gather geographic, ethnographic and political information, often with military and strategic aims. ${ }^{18}$ The final purpose of Scylax's voyage is evident from Herodotus' final words in

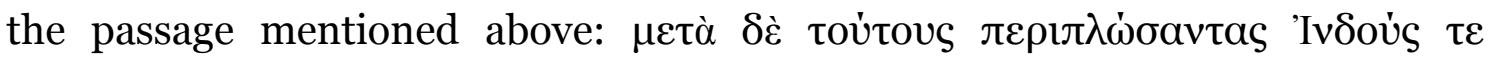

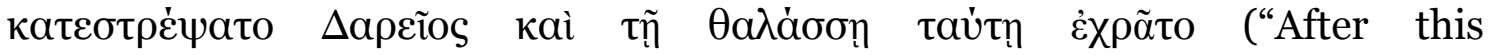
circumnavigation, Darius subdued the Indians and made use of this sea"). There is no certainty that Aristotle had first hand access to Scylax's report, but at least his remark shows that some kind of written account of Scylax's voyage in India circulated in Athens around the fourth century BC.

3. Strabo and the beginning of the confusion between Scylax of Caryanda and the author of the Paris Periplus

Aristotle does not seem to know of a periplus of the Mediterranean by the same author. For the first ancient testimony that ascribes the Paris Periplus

\footnotetext{
${ }^{16}$ See Marcotte 2016:42-47.

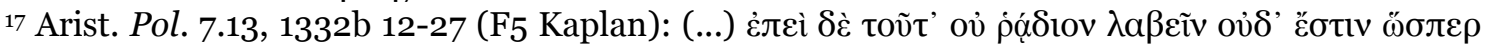

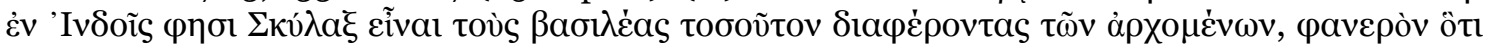

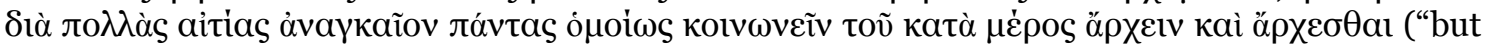
as this is not easy to secure, and as we do not find anything corresponding to the great difference that Scylax states to exist between kings and subjects in India, it is clear that for many reasons it is necessary for all to share alike in ruling and being ruled in turn", transl. H. Rackham). ${ }^{18}$ Cf. Herzfeld 1968:281-285; Kaplan 2008; Marcotte 2016.
} 
to the seafarer Scylax of Caryanda, one needs to look at Strabo's Geography. Discussing Caria and the city-harbour of Caryanda in Book 14, Strabo

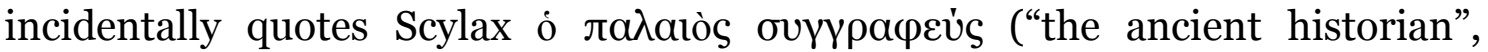
14.2.20 C 658 [T2a Kaplan]). One should point out, with Niebuhr, that the

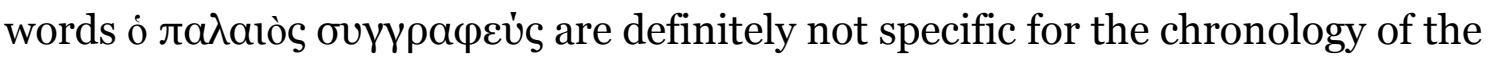
author. ${ }^{19}$ Before that, in Book 12, the same Scylax is mentioned to support the assumption that Bithynia was a Mysian settlement in the first place (12.4.8 C

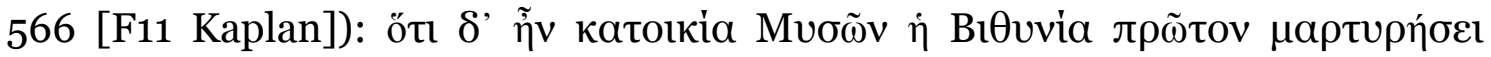

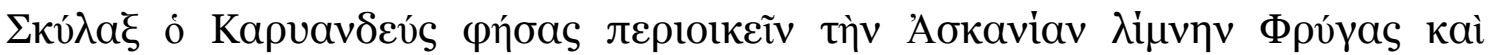
Muбov́s ("that Bithynia was a Mysian settlement is first testified by Skylax the Karyandian, who says that Phrygians and Mysians lived around lake Askania”, transl. D. W. Roller). Now, the text of the Paris Periplus diverges from Strabo's account. There is an entry on the Bithynians (BıOvvoi, Ps.-Scyl. 92) preceding the Mysians (Mvoia, Ps.-Scyl. 93), but the two are distinct from one another. The Paris Periplus does not record any remark on Mysian settlements in Bithynia. Moreover, lake Askania is nowhere to be found in the extant text. Three possibilities arise: (1) the extant Periplus is different from the one that Strabo used; (2) Strabo was careless (quoting from memory?) in the citation of the text; (3) since Strabo lists different ancient authors along with the alleged Scylax (Dionysius author of Foundations, Euphorion, and Alexander the Aetolian), ${ }^{20}$ he was quoting the Paris Periplus through an intermediary source, which would free Strabo from the accusation of deliberately altering the text.

This Strabo passage is very problematic and no definite solution can be envisaged. But it is not the only quotation of Scylax in Strabo: another one can be recognised in 13.1.4 C 582-583 [F12 Kaplan]. ${ }^{21}$ Discussing Aeolis and Homeric geography, Strabo reports that "Scylax of Caryanda has [the Troad] begin at Abydos", which is partly true for the Paris Periplus (Ps.-Scyl. 94-95). Just like the previously discussed passage, Strabo lists here a great number of sources on this disputed geographical question, which points to the fact that he was probably quoting Scylax from an intermediary source. However, what is not

\footnotetext{
19 See Niebuhr 1810:110: "Strabo's Ausdruck «ein alter Schriftsteller» beweiset gar nicht. Für alt galten in Tiberius Zeitalter alle Schriftsteller aus der vormakedonischen Zeit”.

${ }_{20}$ Dionysius: $F H G$, vol.4, 395, fr.7; Euphorion: CA 43 fr.74; Alexander the Aetolian: fr.6 Magnelli.

${ }^{21}$ Counillon 2004:24-25 examines both Strabo's passages under discussion.
} 
at stake here is the fact that Strabo was acquainted with the Paris Periplus, even if quoting it incorrectly, and that in his time it circulated under Scylax's name. We have come thus to a hard fact: in the time of Augustus, i.e., in Strabo's time, the Paris Periplus had already been assigned to the ancient seafarer Scylax of Caryanda, who actually went only to the East and probably brought back a report on Indian customs and geography.

\section{Scylax and the Paris Periplus in the Roman Imperial age}

Just like Herodotus and Aristotle, there are other ancient testimonies for the existence of an account of the eastern (Indian) regions of the oikoumene by the historical Scylax. Harpocration, the second century AD lexicographer,

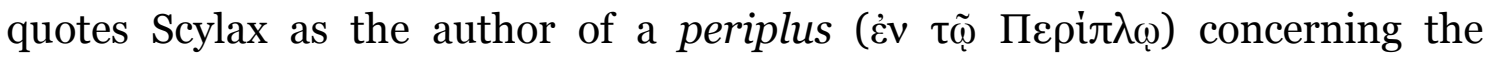
Troglodytae ("cave-dwellers") or, more correctly, Trogodytae. ${ }^{22}$ Herodotus speaks of Ethiopian Trogodytae living in the south of Libya (4.183), but the name has been attached to various tribes and ethne living in Europe, North Africa and Southwestern Asia.23 The problematic identification of the Trogodytae undermines a precise geographical locationing. However, since no mention of the Trogodytae is to be found in the Paris Periplus, we can reasonably suppose that Harpocration was referring either to the historical Scylax or to an account of the Eastern lands falsely attributed to Scylax because of his authority as the first Greek to have sailed the river Indus.

This claim is also supported by another reference to Scylax and the Indian world in Philostratus' Life of Apollonius of Tyana. Philostratus is describing Apollonius' visit to the Indians and uses the geographical context to

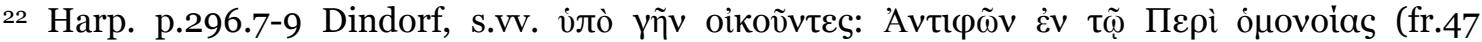

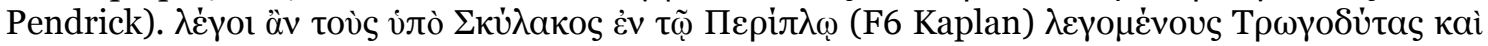

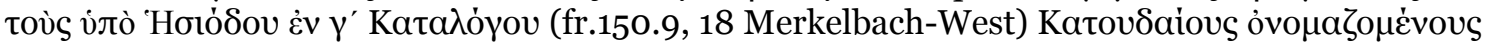
("Dwelling under the earth: Antiphon in On Concord. He may mean the Trogodytes mentioned by Scylax in the Periplus, and those called Subterraneans by Hesiod in the third book of the Catalogue of Women", transl. G.J. Pendrick). Later lexicographic tradition derives from Harpocration: see Phot. $v 182$ and Suda v 465. González Ponce 1997:38 erroneously argues that Antiphon the orator referred to the Periplus of Scylax ("el testimonio más preciado se nos ha conservado en el Léxico de Harpocración y se remonta al orador Antifonte, autor que cita ya una obra de Escílax así titulada...”); a more accurate reading of Harpocration's lemma reveals that

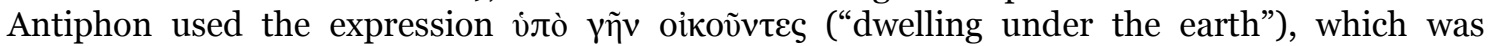
discussed in the interpretamentum by Harpocration: only the latter is accountable for the quotation of Scylax and Hesiod (for the structure of ancient Greek lexicography, see Bossi \& Tosi 1979-1980).

${ }^{23}$ Jahn 1948. For Trogodytai on the African coast of the Red Sea, see Salles 1988:80.
} 
provide a skeptical narrative of the fabulous accounts of the Eastern lands. ${ }^{24} \mathrm{He}$

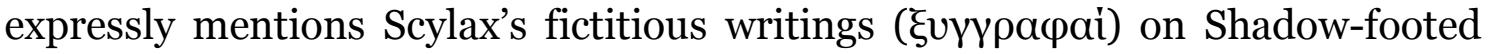

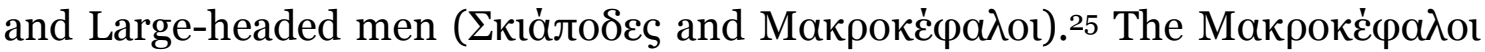
actually appear in the Paris Periplus (85) in the context of the Black Sea region (Colchis), but it has no direct bearing to the question of authorship since Apollonius refers clearly to the author of an account of distant Eastern lands. Ancient sources place Large-headed men in India, Libya or Colchis and they belong usually to mythical and fictitious narratives.

The lack of any hint on both Scylax and the Paris Periplus in the centuries that separate Aristotle from Strabo is most probably the result of the loss of so many Hellenistic literary works dealing with history, geography and ethnography. ${ }^{26}$ It also points to another fact. If on the one hand Herodotus and Aristotle refer to a seafarer and reporter who, despite his distant voyage, appears quite realistic, at a later stage, especially in the writings of Harpocration and Flavius Philostratus, Scylax's account is defined through mythical, fabulous and imaginary elements. Therefore, probably as a consequence of Alexander's conquests in Asia, Scylax was included among the authors of paradoxographical writings on distant lands that flourished in the late Hellenistic age. ${ }^{27}$ Another possibility can also be envisaged: in the Hellenistic age, a paradoxographical work describing India and other Eastern lands was falsely attributed to Scylax as an appeal to his authority.

The tradition that depicts Scylax as the creator of fabulous and mythical accounts of the East is still strongly represented by the twelfth century Byzantine scholar Johannes Tzetzes in his Chiliades (7.629 sq. [F7b Kaplan]). The erudite Tzetzes refers to a book ( $\beta \iota \lambda \lambda$ iov) on the people living around India

\footnotetext{
24 Panchenko 2002 claims that much of Philostratus' account of India depends on Scylax of Caryanda's account, but Jones 2001 argues for a (more probable) variety of sources for Philostratus' narrative.

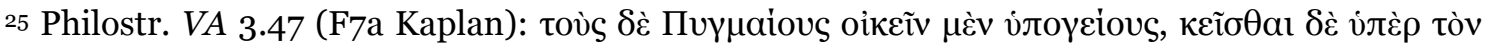

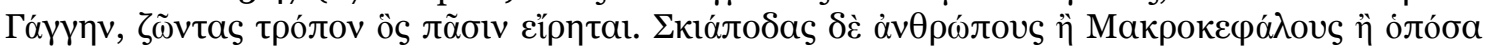

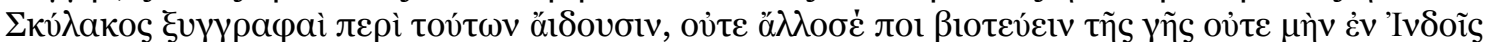
("The pygmies, he said [sc. Iarchas, an Indian sage], lived underground, and they dwell across the Ganges, living in the way that everyone has described. But shadow-footed men, long-headed ones, or all the creatures that Scylax celebrates in his works, these lived neither in other parts of the world nor indeed in India”, transl. C.P. Jones).

${ }^{26} \mathrm{Cf}$. the notorious ratio on surviving against lost Greek historiography of the Hellenistic age in Strasburger 1977:14-15.

27 Cf. Giannini 1963, 1964; Schepens \& Delcroix 1996; Winiarczyk 2011:1-27.
} 
by Scylax of Caryanda: Shadow-footed, Winnowing-fan-eared, One-eyed, Single-bearing men populate the book in Tzetzes's verses. It is unlikely that he had at his disposal Scylax's original work. Since he mentions a book, he was probably referring to a pseudepigraphical work that went under the name of Scylax, which was clearly not the Paris Periplus.

However, there is also another side to the issue of Scylax's ancient tradition: he seems to have had a fundamental role in the history of geographic literature, especially periplography. Rufus Festus Avienus, ${ }^{28}$ at the beginning of his Ora maritima (32-50 [ $\mathrm{T}_{5}$ Kaplan]), lists many ancient logographers and historiographers whom he has allegedly exploited for his verses. The list begins with Hecataeus of Miletus and Hellanicus of Lesbos, and includes Scylax of Caryanda as well as other obscure authors, but it significantly ends with Herodotus and Thucydides, the canonical Greek historians. ${ }^{29}$ Even if Scylax was never included in any "canonical" list of Greek geographers or historians, his presence in this list is a strong indication of his authority in late antiquity. 30

But was Avienus referring to the seafarer of the sixth century BC or to the extant text in the Paris Periplus? The answer lies in another passage of the same work (Or. mar. 370-374 [F8 Kaplan]), where Avienus quotes Scylax in the context of the disputed distance between the shores at the Strait of Gibraltar, i.e., the famous Pillars of Heracles (columnae Herculis):

\author{
sed ad columnas quicquid interfunditur \\ und(a)e aestuantis stadia septem vix ait \\ Damastus esse; Caryandaeus Scylax \\ medium fluentum inter columnas adserit \\ tantum patere quantus aestus Bosp[h]oro est
}

But as to the amount of swirling sea between the Pillars, Damastus says there are scarcely seven stades; Scylax of Caryanda asserts that the water between the Pillars extends as much as the sea does in the Bosporus (transl. J.P. Murphy).

\footnotetext{
${ }^{28}$ On the name and identification of this author, see Cameron 1995.

29 On ancient Greek canonical historians, see Nicolai 1992 and Matijašić 2017 (forthcoming).

$3^{30}$ On the so-called canon of Greek geographers, which was never included among the other ancient literary canons, see Nicolai 1986.
} 
The Paris Periplus (Ps.-Scyl. 1, 111) gives actually the distance between the Pillars as a day's sail, which would be ca. 500 stades or $90 \mathrm{~km}$, way too much: the distance from Gibraltar to Ceuta is $23 \mathrm{~km}$, while the shortest crossing is only $14 \mathrm{~km} .{ }^{31}$ But on the other hand, Damastus (or rather Damastes, see FGrHist 5), who is also mentioned in Avienus' list of sources mentioned above (Or. mar. 46 [ $\mathrm{T}_{5}$ Kaplan]), speaks of seven stades, which is actually the shortest crossing of the Bosporus in the Paris Periplus (Ps.-Scyl. 67).32 It seems quite probable that the author of the Ora maritima was actually using the Paris Periplus, even if quoting it inaccurately and mixing up the information he took from Damastes. Obviously, Avienus used a text which was already (erroneously) assigned to Scylax of Caryanda, an undisputed authority in the field of geographical explorations.

At a later stage in the history of its tradition, the Paris Periplus was widely employed by the anonymous author of the Periplus Ponti Euxini (probably sixth century AD), a compilation of four different peripli: the Periplus of Menippus (known only through Marcian's epitome), Arrian's Periplus of the Euxine Sea, Pseudo-Scymnus' iambic trimeters (only partially preserved), and, finally, the Paris Periplus.33 Moreover, the scholia to Apollonius Rhodius include two fragmentary quotations from the Paris Periplus, 34 but since it is difficult to assign a precise chronology to these scholia (between the first and the sixth century AD), 35 they can be dismissed as not very significant for our understanding of the Periplus's ancient tradition.

We have almost come to the end of antiquity with these latter remarks on Avienus and the Periplus Ponti Euxini, but before we can deal with a fundamental episode in the history of the text of the Paris Periplus, i.e., Marcianus' collection of geographical texts, we should review a testimony that has been used as proof to demonstrate that the historical Scylax was the original

\footnotetext{
${ }^{31}$ The figures in the Paris Periplus refer probably to the distance between Gadeira and some city on the African shore; see Shipley 2011:90.

${ }^{2}$ Cf. Shipley 2011:147.

33 See Diller 1952:1-2, 102-117. For an edition of all the above mentioned texts, see Müller 1855 . The standard edition of the so-called Pseudo-Scymnus (more correctly Iambics to King Nicomedes) is now Marcotte 2000. For the exact places where the Anonymous uses the Paris Periplus, see Diller 1952:107 and Shipley's commentary 2011:passim.

34 These are schol. Ap. Rhod. 1.1177-1178a (p.107 Wendel; F10 Kaplan) and 4.1215 (p.310 Wendel; F9 Kaplan).

35 Cf. Dickey 2007:62-63.
} 
author of the Paris Periplus. We should turn back to the age of the Second Sophistic to consider a passage in Athenaeus' Deipnosophistae (2.70a-c [FF3-4 Kaplan]):

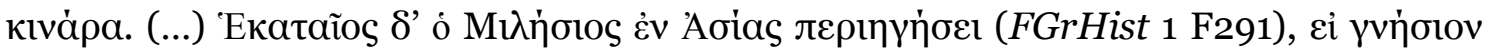

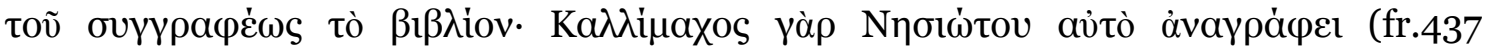

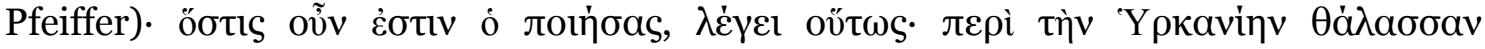

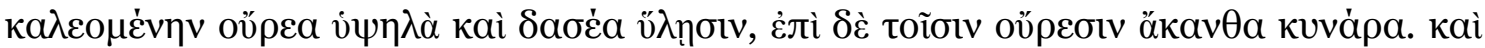

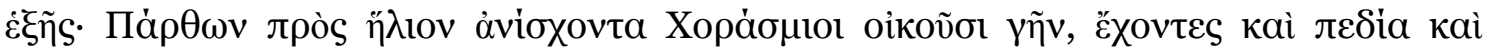

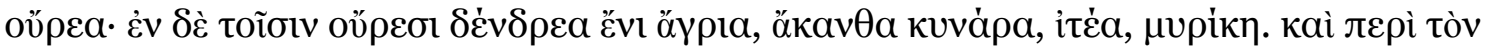

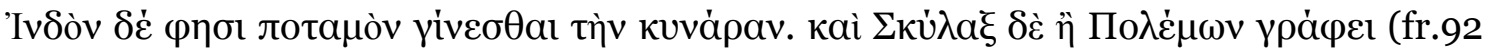

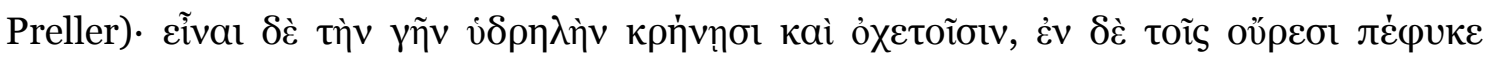

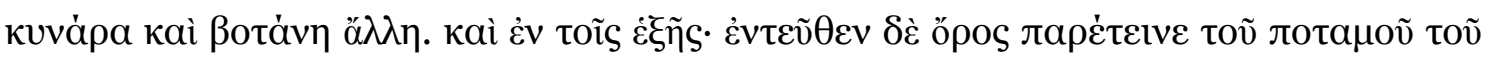

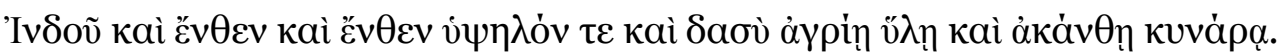

Artichoke. Hecataeus of Miletus in the Tour of Asia, if the book is actually his; because Callimachus ascribes it to Nesiotes. Whoever the author is, therefore, he says the following: Around the so-called Hyrcanean Sea are high mountains covered with thick woods, and cardoon-thorn grows on the mountains. And immediately after this: The territory east of the Parthians belongs to the Chorasmioi, who inhabit both the plains and the mountains. In the mountains are wild trees, cardoon-thorn, willow, and tamarisk. He says that cardoons also grow around the Indus River. Scylax or Polemon as well writes: The land is watered by springs and irrigation channels, and cardoons and other foliage grow in the mountains. And in the section immediately after this: The mountain range extends from here along both sides of the Indus River, and is high and thickly covered by wild trees and bushes and cardoon-thorn (transl. S. Douglas Olson).

In the first place, Athenaeus has doubts on the authorship of the Aoias

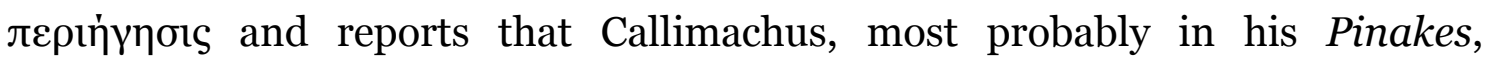
ascribed the work to the unknown Nesiotes. ${ }^{36}$ Since the following description comprises portions of Asia, with many details concerning the flora and the territory (horography, idrography, etc.) that imply an autopsy of the region, the work and its author are probably Hellenistic, and not as early as Hecataeus.

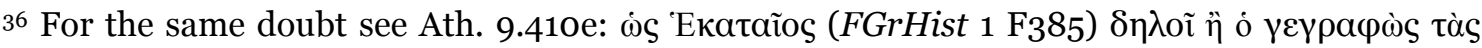

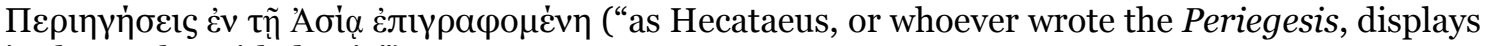
in the work entitled Asia").
} 
Following the description of the Hyrcanian Sea, there comes yet another

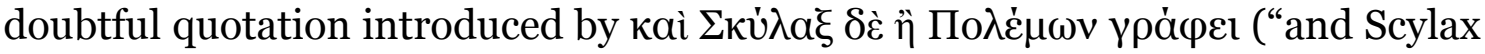
or Polemon writes"). Aurelio Peretti considered this Athenaeus passage to be a fragment of Scylax, even if quoted through Polemon ("un estratto dal resoconto di Scilace, citato nel dialetto originale, sia pure con la mediazione del periegeta Polemone"). 37 However, he seems to be contradicting the textual evidence. There are actually two separate citations: one from a pseudo-Hecataeus, the other from either Scylax or Polemon, a Hellenistic periegetic writer. ${ }^{8}$ Since the section that is attributed to Scylax or Polemon deals uniquely with Indian plants, rivers and mountains, we can exclude that Athenaeus was quoting from the Paris Periplus. His hesitation on the authorship of the passage casts some doubts on the reliability of the fragment itself. But was Athenaeus referring to the real Scylax or to some pseudepigraphic work dealing with India? The question must remain unanswered given that both possibilities are plausible. Concluding this brief review of the authors mentioned in Ath. 2.70a-c, it must be said that it does not represent a reliable testimony for the ancient tradition of the historical Scylax.

\section{Marcianus of Heraclea and the collection of the minor Greek geographers}

A fundamental step in the history of the text of the Paris Periplus is the late-antique geographer Marcianus of Heraclea (fifth-sixth century AD): he collected a corpus of minor ancient Greek geographers which survives in the already mentioned Paris. suppl. gr. 443 (D).39 The corpus was one of the main sources of Stephanus of Byzantium's Ethnika, in the age of Justinian, and was probably exploited by the anonymous author of the Periplus Ponti Euxini.40 Marcianus is also responsible for the introductory note at the beginning of the

\footnotetext{
37 Peretti 1979:61-62.

$3^{8}$ Fragments collected in Preller 1838.

39 See Diller 1952:3-10, 22-26; Marcotte 1986:166; Marcotte 2000:LXXX-LXXXVI. For recent studies on Marcianus, see Altomare 2014-2015 with further bibliography. Marcotte 2000:CXXII, supported by Crinagoras' epigram in Anth. Pal. 9.559, suggests that Menippus, in the age of Augustus, was the original promoter of the collection of minor Greek geographers (see

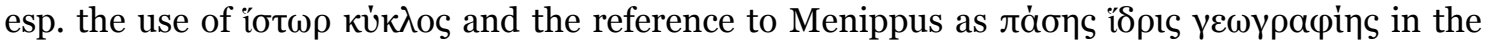
above mentioned epigram).

40 See Marcotte 2000:CXVII-CXIX and CXXVII-CXXX and above, p.10.
} 
Paris Periplus, ${ }^{41}$ where biographical information as well as a summary of the content of the work are presented. ${ }^{2}$ Marcianus' introduction was most probably the direct source of the title of the work and of the brief and confused summary that comes before the text of the Paris Periplus itself:43 the copyist of D, after reading Marcianus' note, reproduced the name of Scylax with the title, adding a few clumsy lines that are supposed to elucidate the subject-matter.

Once we have clarified Marcianus' intervention, we can assume that when he collected his corpus, the Paris Periplus was already assigned to Scylax of Caryanda: Marcianus thus perpetuated the erroneous ascription, added what he knew of Scylax from other ancient sources, and transmitted the error to the copyist of $\mathrm{D}$ and, as a consequence, to modern scholars.

\section{The lexicon of Suda's many Scylaxes}

Finally, in the tenth century AD, in an age of revival of ancient Greek literature, Scylax was the subject of an entry in the Suda lexicon,44 "still the world's most confused source of biographical and bibliographical information", according to Martin L. West.45 The entry is an unreliable patchwork of contrasting sources and mixes up different Scylaxes (Suda o 710 Adler [T1

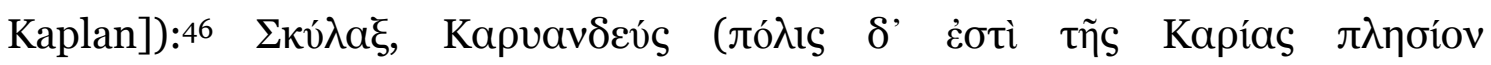

${ }^{41}$ Paris. suppl. gr. 443, ff.62-63. Kaplan (2009: T4) refers to this text as scholia, when he should have probably used another word, such as prolegomena. On scholia and scholiasts, see Wilson 2007. The first scholar to identify Marcianus as the author of the marginal note was Letronne 1840:249, supported later on by Diller's accurate analysis (1952:46).

42 An obscure author is mentioned in Marcianus' note, Aelius Dius, who wrote On Alexandria and said that "Scylax dedicated his work to Darius" (schol. in Ps.-Scyl. 1 [T4 Kaplan]): Aï̀los

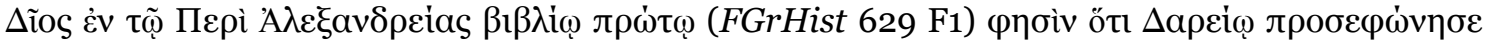

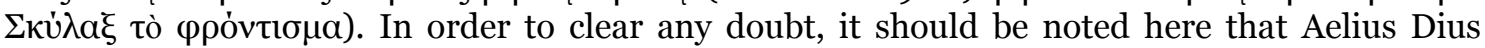
belongs most probably to the second or third century AD (according to his Roman name, a reference to the gens Aelia, cf. Kaldellis 2011), and that he was clearly referring to the historical Scylax when he mentioned Darius: he could have gathered the information in Herodotus.

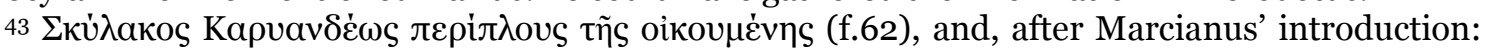

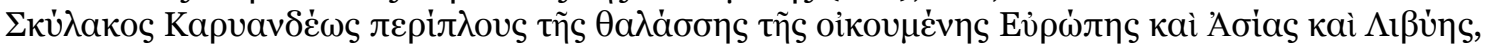

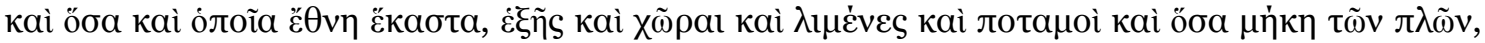

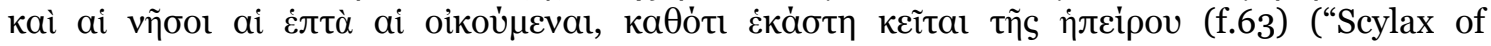
Caryanda's circumnavigation of the sea of the inhabited part of Europe, Asia and Libye, and the number and nature of each ethne, and following the lands and harbours and rivers and the length of the voyages, and the seven islands that are inhabited, as each lies in relation to the mainland"). For a discussion of this text, cf. Shipley 2011:1-2. This latter text is not reported in Kaplan's collection of fragments (2009).

44 Cf. González Ponce 1997:37-38; Schepens 1998; Kaplan 2009: T1; Shipley 2011:5.

45 West 1983:20.

46 As Isaac Vossius already recognised in the Praefatio to his edition of the Periplus (1639):

"Tres enim fuere Scilaces Caryandenses. Antiquissimus est, qui sub Dario, Hystaspis filio, 


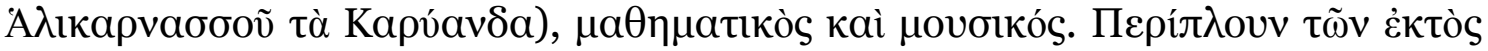

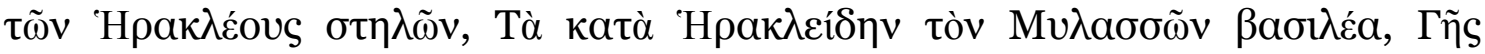

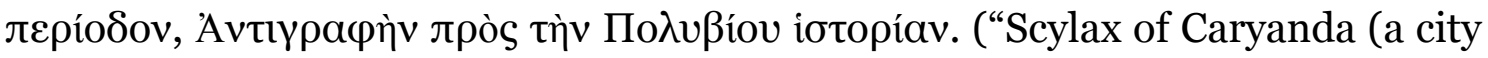
in Caria near Halicarnassus) mathematician and scholar. (Wrote) Account of the Coasting Voyage outside the Pillars of Heracles, The history of Heraclides King of the Mylasians, Circuit of the Earth, Response to the History of Polybius.”).

The author of the entry probably combined two or more distinct authors: the Scylax of Caryanda we have been dealing with so far, and Scylax of Halicarnassus. The latter was known to Cicero as an astronomer and close friend of Panaetius and could be the author of the Response to the History of Polybius. 47 Regarding the history of Heraclides, one Heraclides of Mylasa (àvì $\rho$

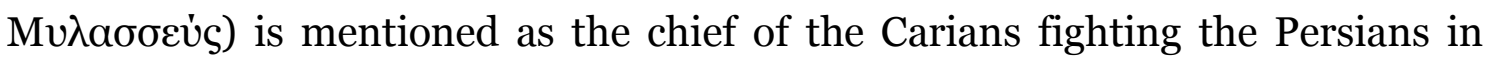
Hdt. 5.121 and in a fragmentary Würzburg-papyrus. ${ }^{48}$ If this Heraclides was a contemporary of Scylax of Caryanda, there is a faint possibility that the latter was the author of Heraclides' biography: it would represent the first attempt by a Greek to write a historical biography. 49 However, nothing else is known of this work except the Suda entry, and we should be very cautious on its attribution. Eventually, the Suda mentions different geographical works: an Account of the Coasting Voyage outside the Pillars of Heracles and a Circuit of the Earth. We can dismiss the account outside the Pillars of Heracles, since it is definitely not

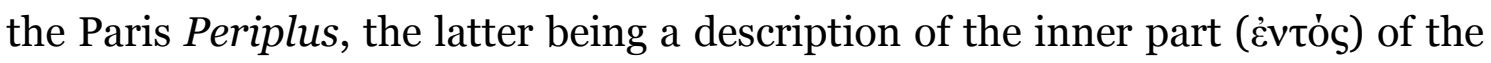
Pillars, i.e., the Mediterranean.50 Regarding the Circuit of the Earth, the words

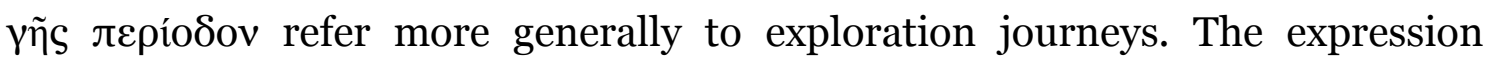

floruit; alter, Darii Nothi; tertius vero, aetate Polybii. (...) Hunc autem Periplum Scilacis, esse

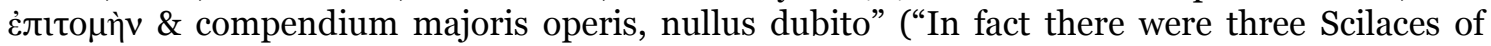
Caryanda: the most ancient lived under Darius son of Hystaspes; the other lived under Darius Nothus; the third lived in the age of Polybius. (...) I do not doubt that this Periplus of Scylax is an epitome and summary of a larger work").

47 Cic. De div. 2.42 (88): Scylax Halicarnassius, familiaris Panaeti, excellens in astrologia idemque in regenda sua civitate princeps, totum hoc Chaldaeicum praedicendi genus repudiavit ("Scylax of Halicarnassus, an intimate friend of Panaetius, and an eminent astronomer, besides being the head of the government in his own city, utterly repudiated the Chaldean method of foretelling the future", transl. W.A. Falconer).

${ }^{48}$ See Wilcken 1906 and further bibliography in Schepens 1998.

49 This was stressed especially by Mazzarino 1966:83-87 and Momigliano 1971:29-30, 44. A detailed and skeptical analysis in Schepens 1998.

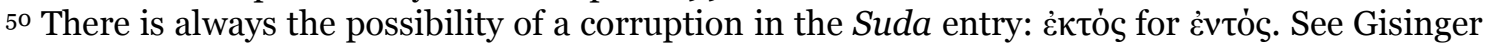
1927:625-626 for such an approach. But it is not always wise to correct a text and make it say what we want to hear. 
indicates a map or a chart in Herodotus, Aristophanes and Aristotle's Meteorology, ${ }^{51}$ while in the Rhetoric the philosopher refers to ai $\tau$ ĩ̃ $\gamma \tilde{\eta} \mathrm{S}$

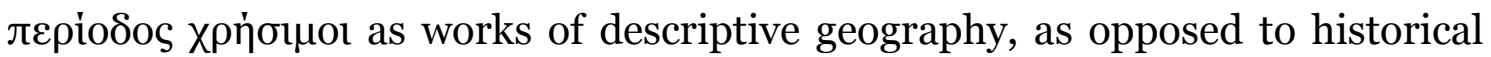

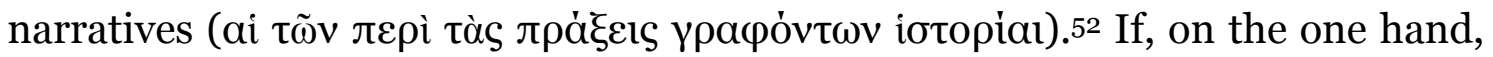

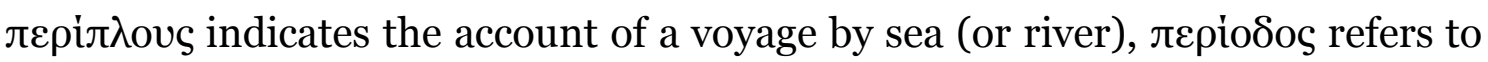
a land-journey, which was not the case either with Scylax of Caryanda or with the Paris Periplus.53 In conclusion, we cannot infer much from the Suda entry, a confused and clumsy source of information.

In the same century when the Suda was compiled, the Byzantine emperor Constantine Porphyrogenitus collected his sources for the De thematibus and noticed the absence of any reference to the Armenian theme in

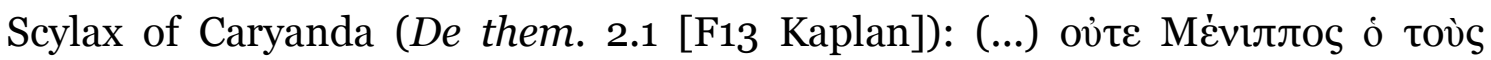

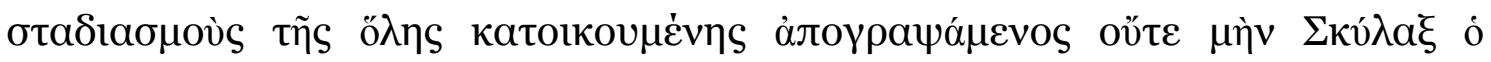

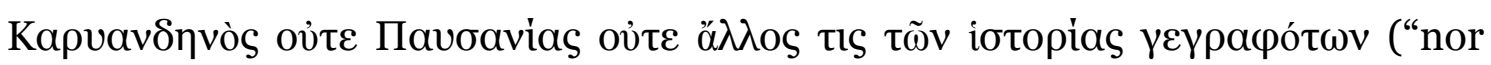
Menippus the recorder of the stade-measurements of the whole inhabited world, nor Scylax of Caryanda, nor Pausanias or any other writers of histories"). Since Scylax is quoted alongside Menippus, it is very probable that Constantine had Marcianus's corpus at his disposal.54 He was therefore influenced by a longstanding (erroneous) tradition on the authorship of the Paris Periplus.

\section{Conclusion}

To sum up, there is no convincing evidence that the extant Paris Periplus is actually related to the historical Scylax of Caryanda, seafarer and explorer in the last decades of the sixth century BC. The confusion on the authorship of the Paris Periplus took place sometime in the Hellenistic age and comes to light as early as Strabo's Geography. It must have resulted from a mixture of ignorance, of an uncompromising will to assign the work to an

\footnotetext{
${ }^{51}$ Hdt. 4.36.2; 5.49; Ar. Nub. 206; Arist. Mete. 350a16; see also Agathem. 1. 52 Arist. Rh. 1360a34; for the same meaning of "descriptive geography" see also Arist. Pol.

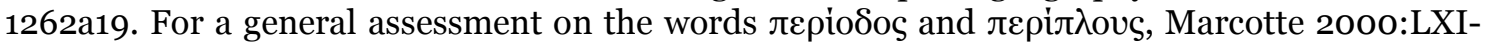
LXVI.

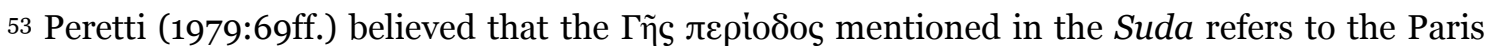
Periplus, but his opinion is preconceived and tautological, based on the assumption that the work must belong to the historical Scylax. Even if the title refers to a lost work by the historical Scylax, it does not demonstrate that it has anything to do with the Paris Periplus.

54 See Marcotte 2016:44.
} 
author, and of Scylax's authority in the subgenre of periplography. It is also probable that other geographical and paradoxographical texts dealing with India were ascribed to Scylax in antiquity, as displayed in Harpocration, Philostratus, and Tzetzes. The authority of Scylax as the first Greek to have visited India must have played a fundamental role in this ancient tradition.

Some scholars have insisted on the hypothesis that the Paris Periplus belongs to the historical Scylax, but it is a preconceived idea based on this ancient error, or rather wilful falsification. The archaising tendency (which to some degree is still alive today) to ascribe a work to a much older author was already flourishing in the age of Augustus, when Strabo quoted a passage from the Paris Periplus but ascribed it erroneously to Scylax. In the early Byzantine period, Marcianus of Heraclea, collecting his corpus of the minor Greek geographers, perpetuated the error and handed it down to the copyist of the Paris. suppl. gr. 443 in the thirteenth century. 


\section{Bibliography}

Altomare, B. (2014-2015) "Périples dans le périple: Notes sur la structure du Périple de la Mer Extérieure de Marcien d'Héraclée et sur sa tradition indirect”, RET 4, 35-53.

Beaumont, R. L. (1934) "Greek influence in the Adriatic before the fourth century B.C.”, JHS 56, 159-205.

Bentley, R. (1699) A Dissertation upon the Epistles of Phalaris. London. $<$ https://archive.org/stream/dissertationuponoobent\#page/n3/mode/2up $>$.

Access on: 24.1.2017.

Bossi, F.; Tosi, R. (1979-1980) "Strutture lessicografiche greche", BIFG 5, 7-20.

Cameron, Al. (1995) “Avienus or Avienius?”, ZPE 108, 252-262.

Corcella, A.; Medaglia, S.M.; Fraschetti, A. (1999) Erodoto, Le Storie. Libro IV: La Scizia e la Libia, seconda edizione, Milano: Fondazione Lorenzo Valla, Mondadori.

Counillon, P. (2004) Pseudo-Skylax: le Périple du Pont-Euxin. Texte, traduction, commentaire philologique et historique. Bordeaux: Ausonius. . (2007) "Le Périple du Pseudo-Skylax et l'Adriatique, § 17-24". In Les Routes de l'Adriatique Antique. Géographie et Économie / Putovi antičkog Jadrana. Geografija i gospodarstvo, éd. par S. Čače, A. Kurilić et F. Tassaux. Bordeaux: Ausonius/Zadar: Presses Universitaires de Zadar, 19-29.

Dickey, E. (2007) Ancient Greek Scholarship. Oxford: Oxford University Press.

Diller, A. (1952) The Tradition of the Minor Greek Geographers (American Philological Association, Philological Monographs, Nr. XIV). Lancaster PA.

Fabricius, B. alias Heinrich Theodor Dittrich (1841) "Über den Periplus des Skylax. I", Zeitschrift für die Alterthumswissenschaften, 1105-1120.

. (1844) "Über den Periplus des Skylax. II", Zeitschrift für die Alterthumswissenschaften, 1081-1103.

. (1878) Anonymi vulgo Scylacis Caryandensis Periplum maris interni cum appendice, Leipzig: Teubner.

Giannini, A. (1963) "Da Omero a Callimaco: Motivi e forme del meraviglioso", RIL 97, 247-266.

Giannini, A. (1964) "Studi sulla paradossografia greca II: Da Callimaco all'età imperiale", Acme 17, 99-138.

Gisinger, F. (1927) “Skylax (2)”, RE 3, A1, 619-646.

González Ponce, F.J. (1997) "Suda, s.v. $\Sigma \kappa \dot{ن} \lambda \alpha \xi$. Sobre el título, el contenido y la unidad de FGrHist III C 709”, Geographia Antiqua 6, 37-51.

Herzfeld, E. (1968) The Persian Empire. Studies in Geography and Ethnography of the Ancient Near East. Wiesbaden: F. Steiner.

Jahn, K. (1948) “Trogodytai”, $R E$ 7, A2, 2497-2500.

Jones, C.P. (2001) “Apollonios of Tyana's passage to India”, GRBS 41, 185-199. 
Kaldellis, A. (2011) “Ailios Dios (629)”, Brill's New Jacoby, Brill Online. Access on: 5.1.2017.

Kaplan, Ph. (2008) "The function of the early «periploi»", ClassBull 84, 27-46. . (2009) "Skylax of Karyanda (709)", Brill's New Jacoby, Brill Online. Access on: 5.1.2017.

Letronne, A.J. (1840) Fragments des poëmes géographiques de Scymnus de Chio et du faux Dicéarque: restitués principalement d'après un manuscrit de la Bibliothèque royale. Paris: Librairie de Gide.

Macan, R.W. (1895) Herodotus. The Fourth, Fifth, and Sixth Books. London: MacMillan and Co.

Marcotte, D. (1986) "Le périple dit de Scylax: Esquisse d'un commentaire épigraphique et archéologique", BollClass 7, 166-182.

. (2000) Géographes Grecs. Vol. I. Introduction Générale. Ps.Scymnos: Circuit de la Terre. Texte établi, traduit et commenté par D. Marcotte. Paris: Les Belles Lettres.

. (2016) "Démocédès de Crotone, l'apographé et la genèse du périple". In La letra y la carta. Descripción verbal y representación gráfica en los diseños terrestres grecolatinos. Estudios en honor de Pietro Janni, ed. por F.J. González Ponce et alii. Sevilla: Universidad de Sevilla, Universidad de Alcalá, 35-49.

Matijašić, I. (2017) Shaping the Canons of Ancient Greek Historiography. Imitation, Classicism, and Literary Criticism. Berlin-Boston: De Gruyter. (forthcoming)

Mazzarino, S. (1966) Il Pensiero Storico Classico. Bari-Roma: Laterza, vol.1.

Momigliano, A. (1971) The Development of Greek Biography. Cambridge MA: Harvard University Press.

Müller, K. (1855) Geographi Graeci Minores, e codicibus recognovit, prolegomenis adnotatione indicibus instruxit, tabulis aeri incisis illustravit $\mathrm{C}$. Müllerus. Paris: Firmin-Didot et sociis, vol.1.

Nicolai, R. (1986) "Il cosiddetto canone dei geografi”, MD 17, 9-24. . (1992) La Storiografia nell'Educazione Antica. Pisa: Giardini.

Niebuhr, B.G. (1810) "Über das Alter des Küstenbeschreibers Skylax von Karyanda”, Abhandlungen in der Akademie der Wissenschaften zu Berlin, reprinted in Kleine historische und philologische Schriften, Erste Sammlung, Bonn: E. Weber, 1828, 105-126.

Panchenko, D. (2002) "Scylax in Philostratus' Life of Apollonius of Tyana", Hyperboreus 8, 5-12.

Peretti, A. (1979) Il Periplo di Scilace. Studio sul Primo Portolano del Mediterraneo. Pisa: Giardini.

Preller, L. (1838) Polemonis Periegetae fragmenta. Leipzig: Sumtibus Guilielmi Engelmanni. 
Salles, J.-F. (1988) “Le circumnavigation de l'Arabie dans l'antiquité classique”. In L'Arabie et ses Mers Bordieres, I. Itinéraires et voisinages. Séminaire de recherche 1985-1986, éd. par J.-F. Salles. Lyon: GS-Maison de l'Orient, 75-102.

Schepens, G.; Delcroix, K. (1996) “Ancient paradoxography: Origin, evolution, production and reception”. In La Letteratura di Consumo nel Mondo GrecoLatino, a cura di O. Pecere e A. Stramaglia. Cassino: Università degli Studi di Cassino, 373-460.

Schepens, G. (1998) "1000 (= 709). Skylax of Karyanda”. In Felix Jacoby, Die Fragmente der griechischen Historiker Continued, IV A.1, ed. by J. Bollansée, G. Schepens, J. Engels, and E. Theys. Leiden-Boston-Köln: Brill, 2-27.

Shipley, G. (2011) Pseudo-Skylax' Periplous. Text, Translation and Commentary. Bristol: Phoenix Press.

Strasburger (1977) "Umblick im Trümmerfeld der griechischen Geschichtsschreibung”. In Historiographia antiqua. Commentationes Lovanienses in honorem W. Peremans. Leuven: University Press, 3-52 (= Studien zur Alten Geschichte, vol.3, Hildesheim-New York: Georg Olms, 1990, 169-218).

Suić, M. (1955) "Istočna jadranska obala u Pseudo Skilakovu Periplu”, Rad JAZU 306, 121-185.

Vitelli Casella, M. (2011) "Il transito degli Argonauti nell'Adriatico settentrionale e centrale: Note geografiche ad A. R. 335-587", RSA 41, 9-23.

Vossius, G.J. (1651) De historici Graecis libri IV, editio altera. Leiden: ex officina Ioannis Maire (reprinted and revised by A. Westermann, Leipzig: Dykian, 1838).

West, M.L. (1983) “Orus' Lexicon: Review of Das attizistische Lexikon des Oros by K. Alpers”, $C R$ 33, 20-22.

Wilcken, U. (1906) "Ein Sosylos-Fragment in der Würzburger Papyrussammlung”, Hermes 41, 103-141.

Wilson, N. (2007) "Scholiasts and commentators", GRBS 47, 39-70.

Winiarczyk, M. (2011) Die hellenistischen Utopien, Berlin-New York: De Gruyter. 